\title{
Temperature and Azimuth angle variation effect on the Building Integrated Photovoltaic Application in Bangladesh
}

\author{
Suman Chowdhury ${ }^{1}$, Md. Abul Bashar ${ }^{2}$, Md. Nazmul Hossain ${ }^{3}$, Anik Talukder ${ }^{4}$ \\ ${ }^{1,2}$ Department of Electrical and Electronic Engineering, International University of Business Agriculture and \\ Technology, Dhaka-1230, Bangladesh \\ ${ }^{3,4}$ Department of Electrical and Electronic Engineering Khulna University of Engineering and Technology \\ Khulna-9203, Bangladesh
}

\begin{abstract}
This paper analyzes the temperature effect on the power generation of building integrated photovoltaic application in Bangladesh. Again this paper shows that how power generation is affected due to variation of azimuth angle. Finally this paper also depicts that how solar irradiation is varied with respect to time duration. From analysis, it is seen that around $10.05 \%$ power increment is occurred when tilt/azimuth angle is varied from $21^{\circ} / 180^{\circ}$ to $21^{\circ} / 0^{\circ}$ at the temperature of $30^{\circ}$ taking consideration of Bangladesh climate.
\end{abstract}

Keywords : Temperature, azimuth angle, solar irradiation.

\section{INTRODUCTION}

Building integrated photovoltaic (BIPV) products are drawing more attention from the building industry as the price of photovoltaic modules continues to drop [1]. Integrating PV systems into the building envelope causes losses in the electrical power production mainly because of three reasons: non-optimal orientation of the modules, shading issues and PV temperature increment [3].The Ex Post BIPV system is an interesting case study to focus on because these three critical aspects are contemporaneously present since it is a façade integration situated in an urban environment and the PV modules are not ventilated [3]. The building is now certified as Klimahaus Gold according to the regional rating scheme, with a calculated energy heating demand of $7 \mathrm{kWh} / \mathrm{m}^{2}$ a. [3]. In advanced countries, buildings consume around $40 \%$ of the total energy consumption, which translates to about $30 \%$ of global carbon dioxide emissions (UN, 2010). For the United States and European Union, buildings account for $37 \%$ of their total energy consumption, while the amount stands at 39\% for the UK (Perez et al., 2008; US GBC, 2007). Within Asia, the energy consumption of buildings is $31 \%$ and $40 \%$ for Japan and Hong Kong, respectively (ECC, 2008) [2]. So the BIPV system is urgent to apply for meeting the energy demand throughout the world. In BIPV system tilt angle and azimuth angle variations cause a significant variation in power generation due to change in temperature level. This paper highlights the influence of azimuth angle on the BIPV application considering temperature issue.

\section{SOLAR IRRADIANCE}

Solar energy is one vital energy source among three main sources which are geothermal, tidal and solar energy. The sun has a black body temperature of $5777 \mathrm{~K}$ (Kelvin) and the diameter of it is of $1.39 \times 10^{9} \mathrm{~m}$ and $1.5 \times 10^{11} \mathrm{~m}$ away from the earth. As shown in figure 1 there is a maximum spectral intensity of $0.48 \mu \mathrm{m}$ wavelength in the green portion of the visible spectrum, in the ultraviolate region $(0.40 \mu \mathrm{m})$ there is $8.73 \%$ energy of the total energy, in the visible region $(0.40 \mu \mathrm{m}$ to $0.70 \mu \mathrm{m})$ there is $38.15 \%$ and in the infrared region $(0.70 \mu \mathrm{m})$ the remaining $53.12 \%$ energy is occupied. The Earth's atmosphere absorbs the ultraviolet (UV) and infrared radiation allowing radiation having wavelength ranging from $0.29 \mu \mathrm{m}$ to $2.3 \mu \mathrm{m}$ known as short wavelength radiation[4]. There are various methods to estimate solar radiation. Satisfactory result for hourly solar radiation estimation was obtained by using atmospheric transmittance model [5] while other authors have used diffuse fraction [6] and clearness index models [7]. Parametric or atmospheric transmittance model requires details atmospheric characteristic information [8]. This model gives high-accuracy for clear sky/cloudless conditions, which is leading some author to use this model to evaluate the performance of an empirical model under cloudless conditions [10]. 



Fig. 2: Solar irradiation data at half hour intervals obtained in KUET campus taking orientation of South $23^{\circ}$ on $7^{\text {th }}$ March 2012.

Figure 2 shows the various levels of solar irradiance in $\mathrm{W} / \mathrm{m}^{2}$ taking the data from 8.00 am to $5.00 \mathrm{pm}$ at a half hour interval on $7^{\text {th }}$ March in 2012 in the KUET campus in Bangladesh. From the data it is seen that the high solar irradiance level was standing between $10.30 \mathrm{am}$ to $2.00 \mathrm{pm}$.

\section{TILT ANGLE AND AZIMUTH ANGLE}

A photovoltaic (PV) system should be installed to maximize the solar contribution to a particular load. Optimum PV inclination and orientation depends on local climate, load consumption temporal profile and latitude [11-13]. The optimum tilt angle is site dependent and calculation of this angle requires solar radiation data for that particular site for the whole year. Normally, during summer, the incident insolation is maximized for a surface with an inclination $10-15^{\circ}$ less than the latitude and, during winter, $10-15^{\circ}$ more than the latitude [14].

Nakamura reported that PV efficiency decreased by $1 \%$ for a horizontal surface than for a $30^{\circ}$-tilted surface due to variation of solar incident angle, solar spectrum and dirt on the module surface for a location at latitude $34.45^{\circ} \mathrm{N}$ and longitude $137.4^{\circ}$ [16]. An experimental study showed that for a location with latitude $35.7^{\circ} \mathrm{N}$ and longitude $51.4^{\circ}$, the maximum PV energy was produced by a surface with tilt angle of $29^{\circ}$ [15].

Fig. 3 shows the initial experimental approach by the researchers for determining the optimum tilt angle for the BIPV system, in which the monthly solar irradiation was $131 \mathrm{KW} / \mathrm{m}^{2}$ and temperature was $25^{\circ} \mathrm{C}$ [9].

Table 1 shows the practical data of voltage and current obtained from a PV module named as KC40REB in KUET campus on $3^{\text {rd }}$ and $7^{\text {th }}$ October 2012 in Bangladesh.

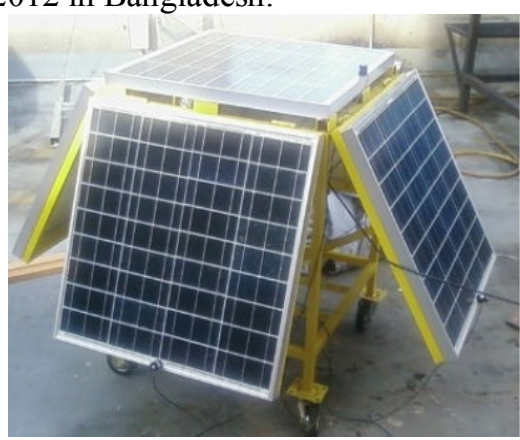

Figure 3: Orientation of PV modules at 4 different slopes [9]. 
TABLE 1: PRACTICAL DATA OF MAXIMUM VOLTAGE AND MAXIMUM CURRENT.

\begin{tabular}{|c|c|c|c|}
\hline Date & Time & $\begin{array}{c}\text { Maximum } \\
\text { Voltage(V) }\end{array}$ & $\begin{array}{c}\text { Maximum } \\
\text { Current(A) }\end{array}$ \\
\hline 3.10 .12 & $8.00 \mathrm{am}-9.00 \mathrm{am}$ & 17.69 & 1.818 \\
\hline 3.10 .12 & $9.00 \mathrm{am}-10.00 \mathrm{am}$ & 17.77 & 1.515 \\
\hline 3.10 .12 & $10.00 \mathrm{am}-11.00 \mathrm{am}$ & 17.59 & 3.25 \\
\hline 3.10 .12 & $11.00 \mathrm{am}-12.00 \mathrm{pm}$ & 17.68 & 2.49 \\
\hline 3.10 .12 & $12.00 \mathrm{pm}-1.00 \mathrm{pm}$ & 17.91 & 2.52 \\
\hline 3.10 .12 & $1.00 \mathrm{pm}-2.00 \mathrm{pm}$ & 17.25 & 0.74 \\
\hline 3.10 .12 & $2.00 \mathrm{pm}-3.00 \mathrm{pm}$ & 17.61 & 1.11 \\
\hline 3.10 .12 & $3.00 \mathrm{pm}-4.00 \mathrm{pm}$ & 17.34 & 0.691 \\
\hline 3.10 .12 & $4.00 \mathrm{pm}-5.00 \mathrm{pm}$ & 16.61 & 0.298 \\
\hline 7.10 .12 & $8.00 \mathrm{am}-9.00 \mathrm{am}$ & 17.34 & 0.615 \\
\hline 7.10 .12 & $9.00 \mathrm{am}-10.00 \mathrm{am}$ & 17.39 & 1.02 \\
\hline 7.10 .12 & $10.00 \mathrm{am}-11.00 \mathrm{am}$ & 17.08 & 1.46 \\
\hline 7.10 .12 & $11.00 \mathrm{am}-12.00 \mathrm{pm}$ & 16.55 & 0.951 \\
\hline 7.10 .12 & $12.00 \mathrm{pm}-1.00 \mathrm{pm}$ & 16.66 & 1.06 \\
\hline 7.10 .12 & $1.00 \mathrm{pm}-2.00 \mathrm{pm}$ & 17.36 & 2.45 \\
\hline 7.10 .12 & $2.00 \mathrm{pm}-3.00 \mathrm{pm}$ & 16.54 & 0.572 \\
\hline 7.10 .12 & $3.00 \mathrm{pm}-4.00 \mathrm{pm}$ & 16.49 & 0.394 \\
\hline 7.10 .12 & $4.00 \mathrm{pm}-5.00 \mathrm{pm}$ & 16.61 & 0.420 \\
\hline
\end{tabular}

Figure 4 shows the practical data for the observation of power obtained from PV module KC40REB in KUET campus taking consideration of a distinct time interval on $3^{\text {rd }}$ and $7^{\text {th }}$ October in 2012.

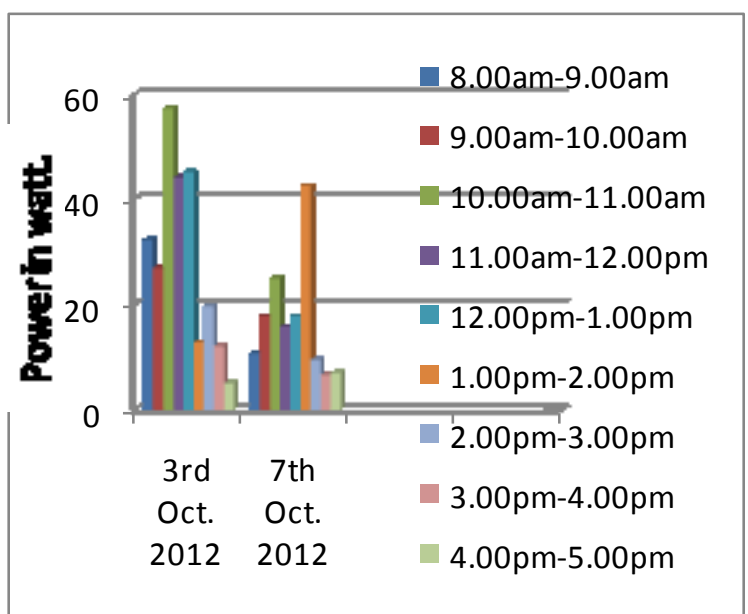

Figure 4: Practically power obtained from PV module KC40REB in KUET campus.

\section{Characterization Of Pv Array Taking The Effect Of Temperature And Azimuth Angle Variation}

For observation of power characteristics of the PV system, two PV arrays are taken where each array consists of 50 strings in parallel and each string consists of 20 modules (Solarex MSX 64) in series connection. From the analysis of power of the PV system, total four different types of figures are obtained. From fig. 5, it is seen that the obtained power is $8.18 \mathrm{KW}$ at the temperature of $22^{\circ}$ whereas that power is incremented to 73.32 $\mathrm{KW}$ at the temperature of $37^{\circ}$ considering tilt/azimuth angle of $21^{\circ} / 0^{\circ}$. Again fig. 6 shows that the obtained power is $9.2 \mathrm{KW}$ at the temperature of $22^{\circ}$ whereas that power is incremented to $61.3 \mathrm{KW}$ at the temperature of $35^{\circ}$ considering tilt/azimuth angle of $21^{\circ} / 180^{\circ}$. So from fig. 5 and fig. 6 , it is seen that more effective power is obtained in the lower azimuth value and power is always getting higher level with increment of temperature in both cases. Now from fig. 7 , it is seen that the best power incremental rate is $92.18 \%$ when temperature is changed from $23^{\circ}$ to $25^{\circ}$ at the tilt/azimuth angle of $21^{\circ} / 0^{\circ}$ whereas in fig. 8, that rate is $62.93 \%$ when temperature is changed from $26^{\circ}$ to $29^{\circ}$ at the tilt/azimuth angle of $21^{\circ} / 180^{\circ}$. 


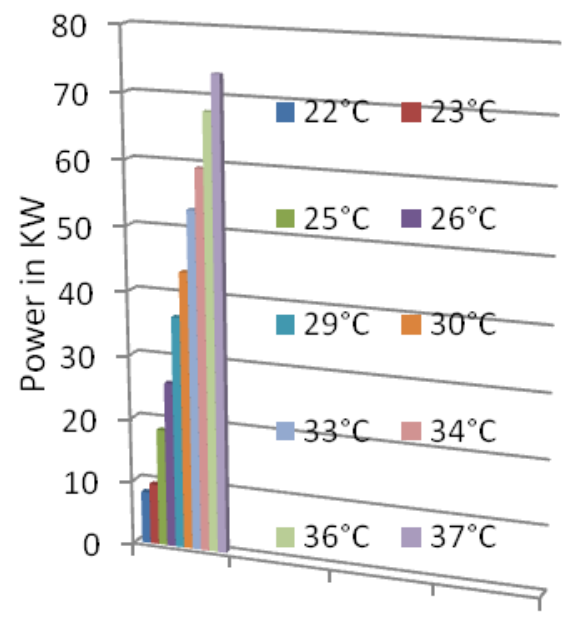

Fig. 5: Temperature effect on power variation with Tilt/Azimuth angle of $21^{\circ} / 0^{\circ}$.



Fig. 6 : Temperature effect on power variation with Tilt/Azimuth angle of $21^{\circ} / 180^{\circ}$.

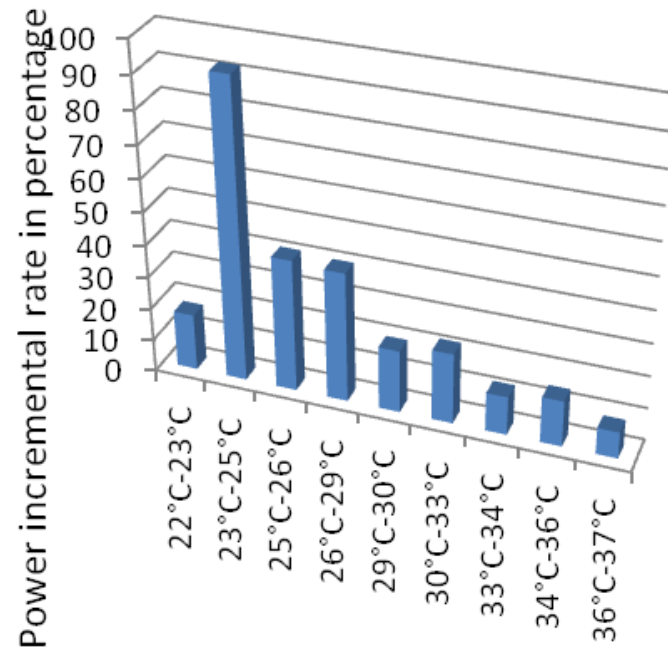

Fig. 7: Power incremental rate with temperature variation at Tilt/Azimuth angle of $21^{\circ} / 0^{\circ}$. 


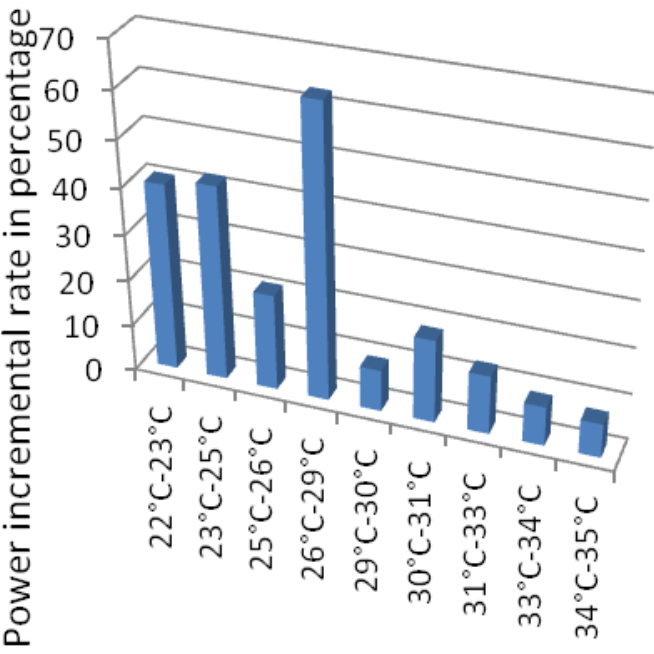

Fig. 8: Power incremental rate with temperature variation at Tilt/Azimuth angle of $21^{\circ} / 180^{\circ}$.

\section{CONCLUSION}

The power generation of the Building Integrated Photovoltaic Application is highly affected by the temperature variation. This paper tries to investigate the influence of temperature on power generation. The azimuth angle variation also takes the good contribution to the effective power generation of the PV system. From the analysis, it is seen that around 6.21 times initial power is obtained when the temperature is changed from $22^{\circ} \mathrm{C}$ to $34^{\circ} \mathrm{C}$ at the tilt/azimuth angle of $21^{\circ} / 180^{\circ}$ whereas it is 7.25 times at the tilt/azimuth angle of $21^{\circ} / 0^{\circ}$.

\section{REFERENCES}

[1] Mark W. Davis, Brian P. Dougherty \& A. Hunter Fanney, Prediction of Building Integrated Photovoltaic Cell Temperatures (Transactions of ASME, the Journal of Solar Energy Engineering, Special issue: Solar Thermo chemical Processing, vol.123, No. 2, PP.200-210, August 2001). http://fire.nist.gov/bfrlpubs/build01/PDF/b01037.pdf

[2] Poh Khai $\mathrm{Ng}$ and Nalanie Mithraratne, "A Selection Framework For The Integration Of Semitransparent Bipv Windows In Singapore", Department of Architecture, School of Design and Environment, National University of Singapore, Singapore, http://www.inta2012.org/papers/inta12-46.pdf.

[3] L. Maturi, W. Sparber ,B. Kofler, W. Bresciani," ANALYSIS AND MONITORING RESULTS OF A BIPV SYSTEM IN NORTHERN ITALY”, Institute for Renewable Energy, EURAC research, Viale Druso 1, 39100 Bolzano (BZ), Italy, http://www.eurac.edu/en/research/institutes/renewableenergy/Publications2/Documents/EURAC_RenEne_PVSEC2010_MaturiSparber-Kofler-Bresciani.pdf.

[4] Joseph Durago, Photovoltaic emulator adaptable to irradiance, temperature and panel-specific I-V curves, California Polytechnic State University, MSEE Thesis, June 2011

[5] G. S. Campbell and J. M. Norman, "Introduction to Environmental Biophysics. 2nd ed. New York: Springer-Verlag. Pp. 167-183, 1998

[6] Reindl DT, Beckman WA, Duffie JA, "Diffuse fraction correlations”, Solar Energy 1990; 45:1-7.

[7] F.J. Batlles et al, "Empirical modeling of hourly direct irradiance by means of hourly global irradiance", Energy 25: 675-688, 2000.

[8] L.T. Wong and W.K. Chow, "Solar radiation model", Applied Energy 69: 191-224, 2001

[9] Z. Abdallah,M. Elhassan,M. Fauzi.Md..Zain, K. Sopian and A. Awadallah, ," Output energy of photovoltaic module directed at optimum slope angle in Kuala Lumpur, Malaysia.”, Research Journal of Applied Sciences, Year-2011, Vol. :6, issue: 2, page no.: 104-109, Doi: 10.3923/rjasci.2011.104.109.

[10] F.J. Batlles, M.A. Rubioa, J. Tovarb, F.J. Olmoc and L. Alados-Arboledas, "Empirical modeling of hourly direct irradiance by means of hourly global irradiance", Energy 25: 675-688, 2000.

[11] Tsalides P, Thanailakis A. Direct computation of the array optimum tilt angle in constant-tilt photovoltaic systems. Sol Cells 1985; 14:83-94.

[12] Kern J, Harris I. On the optimum tilt of a solar collector. Sol Energy 1975; 17:97-102.

[13] Bari S. "Optimum slope angle and orientation of solar collectors for different periods of possible utilization". Energy Convers Manage 2000; 41:855-60.

[14] Duffie JA, Beckman WA. Solar engineering of thermal processes, 2nd ed. Wiley; 1991.

[15] Soleimani EA, Farhangi S, Zabihi MS. "The effect of tilt angle, air pollution on performance of photovoltaic systems in Tehran. Renew Energy" 2001; 24:459-68.

[16] Nakamura H, Yamada T, Sugiura T, Sakuta K, Kurokawa K. "Data analysis on solar irradiance and performance characteristics of solar modules with a test facility of various tilted angles and directions". Sol Energy Mater Sol Cells 2001;67:591-600 